\title{
SYMPATIE JAKO „EKVIVALENT” ATRAKTIVITY OBLIČEJE STÁRNOUCÍCH ŽEN
}

\author{
Lada Pavliková
}

\begin{abstract}
Abstrakt
Atraktivita, včetně obličeje, je pod vlivem evolučních teorií spojována s mládím, reprodukcí a výběrem potenciálního partnera. Za fyzicky atraktivní je v tomto smyslu považována tvář ženy, která vykazuje jasné pohlavně dimorfní (femininní) znaky, je souměrná (symetrická), s průměrnými proporcemi a eventuelně se ostatním jeví jako povědomá. Valná většina prací zabývající se obličejovou atraktivitou využívá k jejímu zhodnocení statických fotografií tváří mladých žen, jejichž věkový průměr nepřesahuje 25 let. Smyslem předkládané studie není upřít mládí jeho atraktivitu, ale pokouší se najít odpověd' na otázku, zdali i tvář ženy nesoucí již známky stárnutí, je ostatními jako fyzicky atraktivní vnímatelná. $\mathrm{S}$ tímto cílem bylo $\mathrm{k}$ hodnocení v předkládané studii využito obličejových fotografií žen ve věku 50 - 65 let, které z hlediska atraktivity hodnotilo 120 respondentů stratifikovaných dle věku a pohlaví do 4 podskupin - mladší ženy (RZM), mladší muži (RMM), starší ženy (RZS) a starší muži (RMS). Ukázalo se, že spojovat stárnutí s fyzickou atraktivitou je pro hodnotitele nepřirozené a tváře, které podle svých slov označili jako „sympatické“, v nich na první pohled vzbuzovaly dojem dobrého charakteru. Zdá se tedy, že u stárnoucích žen je ostatními ceněna spíše jejich „vnitřní krása“ a tím atraktivita osobní v podobě vlastností, postojů, názorů, hodnot či zájmů, které si respondenti do tváří pro ně atraktivních žen promítají.

Klíčová slova: atraktivita, stárnutí, ženský obličej, sympatie, evoluční a sociální psychologie, percepce
\end{abstract}

\section{SYMPATHY AS AN ,EQUIVALENT” TO ATTRACTIVENESS OF AN AGING FEMALE FACE}

\begin{abstract}
Attractiveness, including the face, is under the influence of evolutionary theory associated with youth, reproduction and a mate selection. The physically attractive face in this sense is a woman's face with clear sexually dimorphic (feminine) characters, symmetrical with average proportions and that, which possibly seems familiar to them. The vast majority of work dealing with a facial attractiveness uses for its assessment the static photographs of young women faces, whose average age does not exceed 25 years. The purpose of this study is not to deny the attractiveness of youth, but it is trying to find an answer to the question of whether even woman's face bearing the signs of aging could be perceived as attractive by others. It was therefore used facial photographs of women aged between 50-65 years for evaluation, which were rated by 120 respondents, stratified by age and sex into four sub-groups - younger women, younger men, older women and older men. It turned out that to associate aging with a physical attractiveness is for evaluators unnatural and faces, which, by their own words, have been marked as ,sympathetic" gave to them the impression of a good character at first glance. It seems therefore, that in aging women is valued by others rather their "inner beauty" and a personal attractiveness in the form of traits, attitudes, beliefs, values or interests that respondents can project to, for them attractive, older women face.

Keywords: attractiveness, aging, female face, sympathy, evolutionary and social psychology, perception
\end{abstract}

Došlo do redakce: 28.1 .2014

Schváleno k publikaci: 23. 10. 2014 


\section{Úvod}

O tom, zda je možné ženský obličej vykazující již známky stárnutí vnímat jako fyzicky atraktivní, má většina z nás nejspíše jasnou představu - není. Takové tvrzení je rovněž v souladu $\mathrm{s}$ teoriemi postavenými na základech evoluční biologie, která obličejovou atraktivitu úzce spojuje $\mathrm{s}$ mládím, reprodukcí a výběrem potenciálního partnera (Thornhill, Gangestad, 1999). V tomto duchu ženy s postupujícím věkem na fyzické atraktivitě ztrácí, jelikož jejich „fertilní dny jsou sečteny” a limitace menopauzou je zároveň hranicí, kde možnost být vnímána jako fyzicky atraktivní, pomyslně končí. Zatímco muži podobným omezením čelit nemusí a v často prezentované představě s věkem „pouze zrajı'”, ženy jakoby se bez kosmetických zákroků a péče o vzhled stávaly neviditelnými. V tomto kontextu lze vycítit i jistou formu genderové nerovnosti a Susan Sontagovou definovaný „dvojí standard stárnutí“ (Sontag, 1972). Genderová identita zkušenost se stárnutím ovlivňuje a je s ním rovněž neoddělitelně spjata. Řada studií zabývající se př́stupy vůči stárnutí již v minulosti potvrdila, že starší ženy jsou v porovnání s muži hodnoceny více negativně (Berman, O’Nan, Floyd, 1981; Deutsch, Zalenski, Clark, 1986; Laurence, 1964).

J. M. Ussher, např́íklad, poukazuje na fascinaci současné kultury reprezentacemi stárnoucích žen, které vypadají přitažlivě a stále si udržují mladistvý vzhled. Zároveň ale tvrdí, že „,tyto reprezentace jsou fascinující právě díky př́tomnosti implicitních protikladů věku a atraktivity“ (Ussher, 2006, str. 127). Jak výstižně definuje J. Marhánková Hasmanová: „Vědomí, že součástí těchto reprezentací jsou také retuše, bottoxové injekce a plastické operace, se stává nedílnou součástí tohoto sdělení, které vlastně podporuje představu atraktivity ve stáŕí jako něčeho nepřirozeného“ (Marhánková Hasmanová, 2008, str. 29).

Atraktivita je bezpochyby nejčastěji spojována s fyzickou krásou a vzhledem k roli, jakou v lidské komunikaci hraje obličej, také s ním. Obličej je nejvíce individualizovanou částí lidského těla a tím také typickou charakteristikou jednotlivce. Je zdrojem celé řady sociálních stimulů, přičemž lze člověka podle něj identifikovat, kategorizovat dle pohlaví, věku či etnické př́islušnosti, odhadovat zdravotní stav či emoční rozpoložení, ohodnotit, zdali se nám jeví jako atraktivní a také z něj vycítit jisté osobnostní rysy člověka. Přestože lidé často říkají, že na kráse nezáleží, že u druhých hledají jiné hodnoty, jsou její kulturní výhody nezpochybnitelné. V podstatě každý z nás má tendenci se identifikovat s něčím, co je společensky, sociálně a kulturně vnímané jako krásné. Ovšem převládající trend „mladých a krásných” žen jakoby ty starší zcela vytěsňoval. A možná, trochu paradoxně, právě u žen, jimž fyzická atraktivita po celý život „otevírala dveře”, které byly zvyklé na obletování a pozornost mužů, a které na své kráse stavěly své sebehodnocení, první vrásky rozpoutají nelítostný boj s časem a honbu za kosmetickými zásahy a plastickými operacemi.

Aniž bych se chtěla pouštět do př́lišné kritiky a posuzovat tendence postmoderní kultury prosazující mladistvý vzhled a krásu, ráda bych v následujícím př́íspěvku prezentovala výsledky svého výzkumu poukazující na fakt, že stárnoucí tvář ženy je druhými přitahována a stává se tak pro ně atraktivní ve chvíli, kdy v ostatních vyvolává pozitivní emoce, působí sympaticky, přátelsky a bezproblémově. Jinými slovy řečeno, důležitost fyzické složky atraktivity stárnutím ustupuje do pozadí a rozhodující je v tomto věku přitažlivost osobní, byt' jen přisuzovaná pouhým fotografiím neznámých obličejů žen na základě prvního dojmu.

\section{Teoretické zázemí}

\section{Pohled evoluční biologie}

Tím, co činí tvář atraktivní, se zabývaly generace výzkumníků i umělců z různých perspektiv. Největší část poznatků o charakteristikách fyzicky atraktivních obličejů pochází z oblasti evoluční biologie a to $\mathrm{v}$ kontextu výběru potenciálního partnera $\mathrm{k}$ reprodukci. K charakteristikám fyzicky atraktivní ženské tváře řadí femininní rysy utvářené pod vlivem pohlavních hormonů, obličejovou symetrii, průměrné proporce a povědomost. 
Pozitivní závislost atraktivity ženského obličeje na femininních rysech (Johnston, Barry, 2001) v podobě drobněji vyvinuté dolní části obličeje, ploššího středu, velkých očí, menšího nosu a plných rtů (Thornhill, Gangestad, 1999) ve své podstatě nepřímo poukazují na mládí, jelikož jsou to zároveň rysy typické pro dětský obličej (Mealey, 2000). Naproti tomu je stárnoucí ženský obličej „vystaven“ působení androgenů a tím jisté míře maskulinizace v důsledku změny poměru produkce pohlavních hormonů s nastupující menopauzou, což dojem fyzické atraktivity snižuje.

Poté, co se obličejová symetrie stala tématem pro vědecké bádání, objevují se postupně dvě teorie o jejím vlivu na přitažlivost. První z nich předpokládá roli bilaterálně fungujícího zrakového systému, pro který je, vzhledem k souběžnému zpracování vjemů v obou hemisférách, snazší zpracovat objekty symetrické (Enquist, Arak, 1994) a druhá, podle které symetrické rysy obličeje odráží stabilitu ve vývoji jedince a signalizují dobrý zdravotní stav (Rhodes et al., 2001). Symetričtější obličej je zároveň atraktivnější, jak potvrzuje řada studií (Grammer, Thornhill, 1994; Hume, Montgomerie, 2001; Jones et al., 2001; Simmons et al., 2004; Rhodes et al., 1998; Perrett et al., 1999; Mealey, Bridgstock, Townsend, 1999) a rovněž působí mladším dojmem (Kowner, 1996). Stárnoucí obličej je však z hlediska své fyzické atraktivity pravděpodobně znevýhodněn vznikem nesouměrností, které se $\mathrm{v}$ důsledku změn měkkých tkání $\mathrm{s}$ věkem přirozeně objevují. Jediným aspektem, který by fyzickou atraktivitu i stárnoucího obličeje mohl podpořit, je obličej, který hodnotiteli z nějakého důvodu připadá povědomý (Monin, 2003).

Zajímavou se v souvislosti s fyzickou atraktivitou stává hypotéza průměrných obličejů a to i pro způsob, jak byla objevena. Autorem tohoto zjištění je Francis Galton, který byl zvědav, zda obličeje lidí, jež v určité sociální skupině spojuje nějaký společný jmenovatel, vykazují specifické rysy. Ve snaze najít odpověd', vytvářel v 80. letech 19. století kompozitní snímky zločinců a vegetariánů v naději, že odhalí typické obličejové znaky obou dvou skupin. Zatímco výsledná „zprůměrovaná“ kompozita nedovolovala žádnou a priori identifikaci zločince či vegetariána, Galton s překvapením zjistil, že tvář na kompozitním snímku byla atraktivnější, nežli ta původní (Rubenstein, Langlois, Roggman, 2002; in Rhodes, Zebrowitz, 2002). Od počátku 90. let se tvorba kompozitních snímků (dnes s pomocí počítačů) stává běžnou metodou pro výzkum fyzické atraktivity obličeje. Průměrnost v tomto smyslu znamená jakýsi ideál vykazující v obličeji všechny fyzické znaky průměrnou měrou a představuje tak určitý „,prototyp“. Průměrné tváře jsou typičtější, vzájemně si podobnější a tím také povědomější. Díky tomu jsou preferovány jako nejsnáze rozpoznatelné. Pravdou však zůstává, že takové zprůměrování je ve své podstatě arteficiální a vede k „vylepšení“ skutečných tváří vyhlazením extrémních vlastností (Grammer, Thornhill, 1994).

\section{Pohled sociální psychologie}

Z předchozích odstavců plyne, že evoluční biologie, jejíž studium atraktivity zdá se být doposud nejintenzivnější, se ve svých výzkumech soustředí zejména na její fyzickou komponentu a do „,̌ela“ svých teorií staví zejména mládí a reprodukci. Lidé se však nechovají podle diktátu genetického programu zaměřeného na vzdálený evoluční cíl vlastní reprodukce za všech okolností a stárnutí, které je v prrípadě zde prezentované studie nepřehlédnutelným atributem, je „okolnost“, která takové tvrzení bezesporu potvrzuje. Pohled na atraktivitu z úhlu sociální psychologie se tudíž v tomto ohledu zdá být smysluplnější.

„Atraktivita se vztahuje k jedinci nebo skupině osob, jejichž nějaká vlastnost či vlastnosti jsou pro jiné jedince zdrojem odměn. Fyzické a osobní vlastnosti vyvolávají př́ímou nebo kognitivními procesy zprostředkovanou pozitivní emoční odezvu a nositelé těchto vlastností mohou uspokojovat nejrůznější potřeby těch, pro které jsou přitažliví“. (Slaměník, Výrost, 2008, str. 252).

Přidržíme-li se nyní výše uvedené definice atraktivity v sociální psychologii, která ji vnímá jako vlastnosti (fyzické či osobní), jež v ostatních vyvolávají pozitivní emoční odezvu a jsou tak pro ně zdrojem odměn, dostáváme se ke stejnému úhlu pohledu, jakým na atraktivitu stárnoucího ženského obličeje nahlíželi hodnotitelé ve zde prezentovaném výzkumu. 


\section{Cíl výzkumu}

Metody většiny doposud publikovaných prací o fyzické atraktivitě ženského obličeje zahrnují její hodnocení u žen mladší věkové kategorie (v prüměru kolem 25 let), přičemž toto hodnocení probíhá mezipohlavně a $\mathrm{v}$ jeho podtextu se skrývá jediný cíl - výběr potenciálního partnera $\mathrm{k}$ reprodukci. Zde prezentovaná studie se $\mathrm{v}$ hodnocení atraktivity zcela záměrně soustředila na obličeje stárnoucích žen, čímž bylo eliminováno mládí jako jedna z proměnných, která s fyzickou atraktivitou ženského obličeje koreluje prokazatelně pozitivně.

Cílem tedy bylo především ověřit, zdali i obličeje žen nesoucí již známky stárnutí, jsou ostatními jako fyzicky atraktivní vnímatelné a polostrukturovaným rozhovorem následně objasnit, zdali fyzicky atraktivnímu obličeji ostatní přisuzují pozitivní osobnostní vlastnosti, potažmo připisují-li jim rovněž atraktivitu osobní.

\section{Výzkumné otázky}

1. Jsou obličeje stárnoucích žen vnímatelné v kategoriích fyzicky atraktivní/neatraktivní?

2. Liší se náhled na fyzickou atraktivitu obličeje stárnoucích žen mezi respondenty různého věku a pohlaví?

\section{Výzkumný soubor a použité metody}

V rámci šetření byla zvolena smíšená výzkumná strategie kombinující kvantitativní př́istup párového srovnávání (paired comparison) statických obličejových fotografií následovaný kvalitativně zaměřeným polostrukturovaným rozhovorem. Volba techniky párového srovnávání se zdála být vhodnější, nežli v tomto kontextu běžně užívané škálování, a to zejména z následujícího důvodu. Především se jedná o metodu tzv. nucené volby, kdy se respondent na základě předem daného kritéria, $v$ našem př́ípadě atraktivity, musí rozhodnout pro jednu položku z páru (Kerlinger, 1972). Byt' se to může na první pohled jevit jako složité, zvláště v př́ípadě, kdy má respondent pocit, že ani jedna položka $z$ páru nevyhovuje jeho představám, je proces rozhodování přece jen každodenní lidskou činností a pro mysl člověka přirozenější, nežli sestavování pořadí a stupnic. Po skončení párového srovnávání se $\mathrm{v}$ rámci polostrukturovaného rozhovoru měli respondenti vyjádřit k osobnostním vlastnostem, postojům, sociálnímu postavení, hodnotám či zájmům, které přisuzují obličeji ženy, jež předtím označili za nejsympatičtější.

Výzkumný vzorek 120 respondentů byl získán technikou stratifikovaného výběru, přičemž k zajištění dostatečné reprezentativnosti byli respondenti vybíráni do čtyř podskupin definovaných věkem a pohlavím (30 mužů s věkovým průměrem 22,3 let a SD 2,53; 30 mužů s věkovým průměrem 55,3 let a SD 3,21; 30 žen s věkovým průměrem 21,9 let a SD 2,53 a 30 žen s věkovým průměrem 55,6 let a SD 3,24). 92 \% respondentů mělo minimálně středoškolské vzdělání. Jednalo se o 55 studentů vysoké školy, 23 respondentů s ukončeným vysokoškolským a 32 s ukončeným středoškolským vzděláním. Polovina byla svobodná a bezdětná $(50 \%), 39 \%$ žilo v manželství či partnerství a $11 \%$ respondentů žijí sami, jsou rozvedeni nebo vdovy/vdovci. Jednalo se tedy o soubor středoškolsky až vysokoškolsky vzdělaných respondentů proporcionálně zastoupených dle věku a pohlaví, z nichž polovina byla svobodná a téměř polovina žila v manželském či partnerském svazku.

Z hlediska fyzické atraktivity měly být hodnoceny obličeje žen ve věkovém rozmezí 50-65 let, jejichž fotografie byly zaneseny do dotazníků párového srovnávání vytvořených aplikací Anthropac užívané zejména v oblasti kognitivní antropologie, a to nejen jako účinný nástroj pro přípravu, ale zároveň i následnou analýzu dat. Fotografie byly pořízeny digitálním přístrojem Nikon D300s z pohledu „en-face“ vždy na světlém pozadí. Všichni účastníci byli nejprve seznámeni s výzkumným účelem př́padného použití jejich fotografií a teprve po vyslovení souhlasu byli 
vyfotografováni. Účastníci byli vyzváni k odložení brýlí, k přímému pohledu do objektivu a udržení neutrálního výrazu po dobu fotografování. Vzniklé fotografie byly uloženy ve formátu .jpg a následně upraveny v programu Adobe Photoshop CS4 tak, aby uprostřed výsledného snímku zůstal pouze obličej a pozadí bylo čistě bílé. Každá z deseti fotografií dostala přidělený kód Z1-Z10 označující ženské pohlaví a číslo fotografie. Hodnotitelé měli vždy nejprve určit fyzicky atraktivnější obličej ženy u 45 párů pořízených z 10 individuálních fotografií, přičemž každý z obličejů (Z1-Z10) mohl v jednom dotazníku získat maximálně 9 a minimálně 0 bodů. Ve snaze identifikovat důvody, které hodnotitele vedly $\mathrm{k}$ přiřazení atraktivního atributu právě $\mathrm{k}$ danému obličeji, byl s každým z nich proveden polostrukturovaný rozhovor cílený především na první dojmy, které v nich pro ně nejatraktivnější tvář vyvolává ve vztahu ke vzdělání, sociálnímu postavení a osobnostním rysům.

\section{Výsledky}

Respondenti v tomto výzkumu jakoby vzdorovali tomu, aby obličeje hodnotili z hlediska atraktivity fyzické. Zcela přirozeně je všichni označovali za sympatické či nesympatické, přičemž sympatie přisuzovali těm fotografiím žen, které v nich na první pohled vzbuzovali dojem dobrého charakteru.

Následně kvantitativní analýzou párového srovnávání nebyla potvrzena existence konsensu v náhledu na sympatie obličejů stárnoucích žen a bez statisticky významného rozdílu ( $>0,05)$, prokázaného t-testem, se o první místo dělí tř̌ ženské obličeje ve výzkumu figurující pod kódovým označením Z10, Z5 a Z8 (obrázek 1), do jejichž hodnocení se promítá odlišný věk a pohlaví hodnotitelů (tabulka 1).

Obrázek 1. Relativní četnosti fotografií ženských obličejů (Z1-Z10) z hlediska hodnocení sympatií

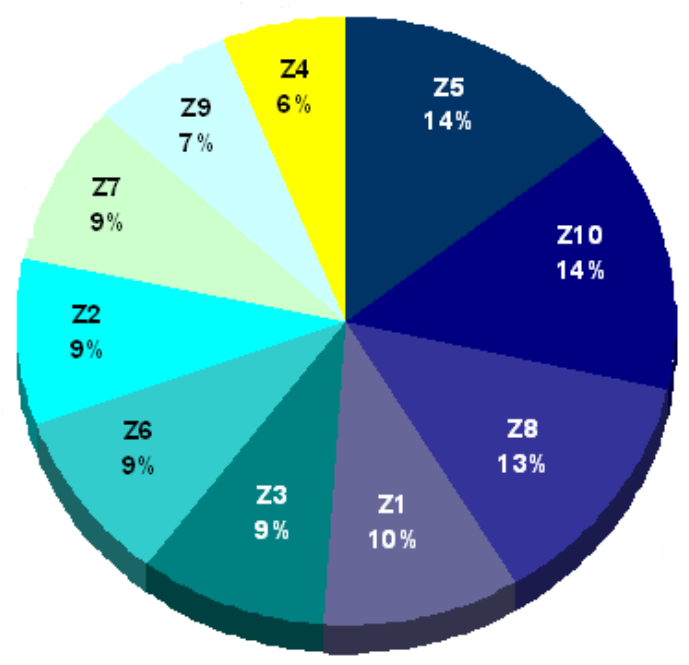




\section{-psychologie}

Tabulka 1. Absolutní četnosti nejsympatičtějších hodnocení v jednotlivých podskupinách respondentů

\begin{tabular}{|c|c|c|c|c|}
\hline \multicolumn{5}{|c|}{ TABULKA ABSOLUTNÍCH ČETNOSTí U RUZNÝCH } \\
SKUPIN RESPONDENTÚ \\
\hline $\begin{array}{c}\text { FOTOGRAFIE } \\
\begin{array}{c}\text { ŽENSKÝCH } \\
\text { OBLIČEJU் }\end{array}\end{array}$ & $\begin{array}{c}\text { RMM } \\
\text { mladší } \\
\text { muži }\end{array}$ & $\begin{array}{c}\text { RMS } \\
\text { starší } \\
\text { muži }\end{array}$ & $\begin{array}{c}\text { RZM } \\
\text { mladšíi } \\
\text { ženy }\end{array}$ & $\begin{array}{c}\text { RZS } \\
\text { starší } \\
\text { ženy }\end{array}$ \\
\hline $\mathbf{Z 1}$ & 132 & 131 & 123 & 142 \\
\hline $\mathbf{Z 2}$ & 124 & 143 & 110 & 103 \\
\hline $\mathbf{Z 3}$ & 103 & 124 & 137 & 133 \\
\hline $\mathbf{Z 4}$ & 63 & 82 & 78 & 102 \\
\hline $\mathbf{Z 5}$ & 192 & $\mathbf{2 0 5}$ & 185 & 198 \\
\hline $\mathbf{Z 6}$ & 129 & 110 & 130 & 127 \\
\hline $\mathbf{Z 7}$ & 135 & 113 & 101 & 113 \\
\hline $\mathbf{Z 8}$ & 167 & 144 & $\mathbf{2 0 5}$ & 166 \\
\hline $\mathbf{Z 9}$ & 107 & 106 & 105 & 65 \\
\hline $\mathbf{Z 1 0}$ & $\mathbf{1 9 8}$ & 192 & 176 & $\mathbf{2 0 1}$ \\
\hline
\end{tabular}

\section{Podskupina respondentů - starší ženy o věkovém průměru 55,6 let}

Starší respondentky, tedy ženy stejné věkové kategorie jako ty, které hodnotily, označily jako nejsympatičtější obličej skrývající se pod označením Z10. Viděly v ní svůj vzor přiznávajíce, ...,žze by rády vypadaly jako ona“. Paralelně s tím v ní viděli ženu ...,,inteligentní a vzdělanou, ušlechtilou, ochotnou a vstřícnou, př́jemnou, optimistickou, spokojenou, věrohodnou, vyrovnanou, oblíbenou a št'astně vdanou“.

\section{Podskupina respondentů - mladší muži o věkovém průměru 22,3 let}

Tvář s označením Z10 byla jako nejsympatičtější vyhodnocena také skupinou mladších mužů. Přiznávají jí krásu a zároveň si o ní vytvářejí obraz „typické učitelky, zdravotní sestry či sociální pracovnice“, tedy obraz role, ve které by rádi, aby ve společnosti vystupovala. Představují si tak ženu, která by je měla vzdělávat a ošetřovat, jinak řečeno nejsympatičtější je pro ně v tomto věku žena, která o ně bude dobře pečovat.

\section{Podskupina respondentů - starší muži o věkovém průměru 55,3 let}

V protikladu s mladšími muži a staršími ženami byla ve skupině starších mužů označena jako nejsympatičtější tvář Z5. Podle nich ...,,nemá v tváři vepsánu skepsi, kterou by v tomto věku očekávali, působí pozitivně, př́jemně, upřímně, je nekonfliktní, férová, obětavá, chytrá, hodná, pracovitá, sportovně založená a domnívají se, že pracovala nebo ještě pracuje s lidmi“. Zdá se, že právě tyto atributy jsou pro muže stejné věkové kategorie přitažlivější.

\section{Podskupina respondentů - mladší ženy o věkovém průměru 21,9 let}

V této skupině zvítězila tvář Z8, do které si dívky promítaly roli zdravotní sestry či lékařky, která ...,to umí s dětmi, pracuje s lidmi, je vzdělaná, hodná, inteligentní, citlivá a lidé ji mají rádi““. 


\section{Diskuse}

Již od počátku výzkumu začínalo být zřejmé, že v souvislosti se stárnutím je pro většinu respondentů (75\%), a to bez ohledu na věk či pohlaví, nepřirozené posuzovat stárnoucí obličej z hlediska atraktivity fyzické, kterou vnímají jako atribut mládí. V tomto ohledu se lze ztotožnit $\mathrm{s}$ teoriemi fyzické atraktivity vycházejícími ze studií evolučně orientovaných autorů.

Lidská tvář se postupně vyvíjí a posléze stárne obdobně jako celý organismus. Nejvíce patrné jsou změny na kủži, která se po 45. roce začíná ztenčovat a to částečně i v důsledku hormonálních změn. Kůže se stává křehčí, zranitelnější a citlivější, snáze se poruší a hưře se hojí. Především však přibývá vrásek. V souvislosti se stárnutím se tak přirozeně objevuje obličejová asymetrie a různé nerovnosti, které v součinnosti s hypotézami o symetrii a průměrnosti s atraktivitou korelují negativně. Ženy obecně více pečují o svůj vzhled a různé kosmetické př́ípravky a zásahy plastické chirurgie jim umožňují vyrovnávat nerovnosti a asymetrie stárnoucího obličeje ve snaze udržet si co nejdéle mladistvý vzhled i s výhodami, které jim přináší. Přesto však je v očích většiny hodnotitelů nepřirozené spojovat fyzickou atraktivitu s procesem stárnutí a jimi preferované obličeje jsou jim spíše sympatické a to především pro kladné osobnostní rysy, které dané tváři připisují. Nicméně v príípadě podskupiny starších žen $(25 \%)$, které v podstatě hodnotily obličeje žen stejné věkové kategorie, se objevuje snaha přisuzovat sympatie takovému obličeji, kde je patrná větši kosmetická péče o něj.

Základním kritériem při zhotovování obličejových fotografií žen určených k následnému hodnocení bylo věkové rozmezí 50-65 let. Každá z účastnic byla požádána o odložení brýlí, př́mý pohled do objektivu a udržení neutrálního výrazu, což jsou standardní požadavky doposud používané ve studiích s tematikou obličejové atraktivity. Přes veškerou snahu a opakované požádání o nastolení neutrálního výrazu, se tento požadavek u žen ovšem nepodařilo splnit bezezbytku a v podstatě každý z obličejů naznačuje více či méně nějakou emoci. Ve snaze dodržet základní kritérium v podobě náhodného výběru, bylo do následného hodnocení nakonec zařazeno všech deset fotografíi.

Jedním z charakteristických rysů stárnoucího obličeje je přeměna tzv. dynamických vrásek, které vznikají kontrakcí (stahováním) mimických svalů, do podoby vrásek statických, tedy jakýchsi neměnných záhybů kůže zasahujících do jejích hlubších vrstev. Tento úzký vztah mezi aktivitou mimických svalů a tvorbou vrásek evokuje i představu o tom, že během života častěji užívaný mimický výraz (at' již pod vlivem aktuálně prožívaných emocí, nebo hraný v rámci sociálních postojů) se může charakteristickými druhy vrásek ,vtisknout“ do stárnoucího obličeje. Zjištění, že účastnice našeho výzkumu nebyly schopny nastolit neutrální výraz při fotografování, se tak shoduje i se závěry italských psychologů, kteří tvrdí, že u starších osob se do výrazu, který by měl být neutrální, promítají emoce, které člověk v životě prožival nejčastěji (Malatesta, Fiore, Messina,1987). Př́ípadný náznak emoce ve stárnoucím obličeji dobrovolnic našeho výzkumu nebyl aktuálně hraný. Byl spíše odrazem jejich emočního života či možným důsledkem kosmetických zásahů (jako např. pravděpodobný facelift u Z10) a jako takový také možným kriteriem sloužící respondentům k hodnocení obličejové atraktivity/sympatie ve starším věku.

Obličej Z10 byl jako nejsympatičtější označen dvěma podskupinami respondentů lišících se věkem i pohlavím a to ze zcela jiných důvodů. Jednalo se o tvář ženy s vyčesanými vlasy dozadu, odhaleným vysokým čelem s téměř žádnými vráskami, upraveným obočím a náznakem úsměvu, který nedokázala skrýt při opakovaném pokusu o nastolení neutrálního výrazu. Zdá se, že v tomto př́padě byl obličej udržován pravidelnými kosmetickými zásahy, což ve svém důsledku mohlo vést k mylnému dojmu mladšího věku. Starší respondentky tuto ženu obdivovaly, chtěly by vypadat jako ona, jakoby ony samy podporovaly přežívání „mýtu krásy“a podvolovaly se tak kulturnímu imperativu mladistvého vzhledu. Jakoby si stárnoucí žena musela mladický vzhled stále udržovat, aby mohla být zároveň v životě spokojená. Pojem „mýtus krásy” poprvé použila ve své stejnojmenné knize americká feministka Naomi Wolfová, která v ní ideál ženské krásy označuje za uměle vytvořený mýtus, sociální konstrukt, který je ve své podstatě namířen proti ženám. Domnívá se, že neexistují žádné přirozené prríčiny, které by mohly zdůvodnit skutečnost, že právě velké oči, 
plné rty a symetrická tvář jsou západní společností považovány za krásné v porovnání s jinými rysy. Tvrdí, že tyto rysy byly jen symbolicky zvýrazněny tím, že byly jako „krásné” označeny.

V roce 1996 vychází studie Ferjenčíka a Nišponské, ve které se autoři zaměřili na ověřování vztahu mezi výrazem tváře a sociální rolí. Uvádějí, „že si lidé vytvářejí konzistentní obrazy o nositelích určitých sociálních rolí“ a svými výsledky potvrzují existenci jistých „rolových stereotypů“ (Ferjenčík, Nišponská,1996, str. 44). Tento úhel pohledu je možné vypozorovat i v př́ípadě respondentů mužů mladší věkové kategorie, kterým se i tentokrát jevil jako nejsympatičtější obličej ženy s označením Z10. Dle tváře této ženy usuzovali, že je „učitelkou, zdravotní sestrou či sociální pracovnicí“ a svým způsobem jí tak přisoudili sociální roli - roli pečovatelky.

Jakýsi zvrat v hodnocení je patrný ve skupině respondentů mužů starší věkové kategorie. Celkově $v$ této skupině byla za nejsympatičtější označena tvář ženy Z5, ve které vidí „,bezproblémového přítele“. Pokud u některých z nich zvítězila Z10 jako u předchozích skupin, hodnotili ji poněkud povrchněji jako ...,,ženu pracháče“, pěstěnou, po plastické operaci, jako ženu emancipovanou, žijící ve vile, ženu, která si jde za „svým“ a které „dělají chlapi dobře“. Muži jakoby se její atraktivity, potažmo sympatií, obávali s pocitem, že by jim byla nevěrná a že by jí byli „tlačeni“" $\mathrm{k}$ vyšším výdělkům.

Mladé ženy vidí sympatie žen vyššího věku spíše než v kráse, ve ...,schopnosti s nimi dobře vyjít i přes jejich mládi'“ a tyto představy si promítly do tváře ženy s označením Z8.

Jak již bylo zmíněno dříve, respondenti v tomto výzkumu jakoby vzdorovali tomu, aby obličeje hodnotili z hlediska atraktivity a zcela přirozeně je označovali za sympatické či nesympatické. Jak uvádí I. Slaměník: „V našich kulturních podmínkách i v odborné psychologické literatuře je sympatie chápána jako citlivá náklonnost, pozitivní vztah k někomu či něčemu a má blízko k atraktivitě“ (Slaměník, 2011, str. 137). Obrátíme-li se k výkladu původu výrazu atraktivita, zjistíme, že je odvozen od slova at-trahere - přitahovati, a tudíž nemusí být spojován jen s krásou a vzhledem jedince, ale se vším, co z nějakého důvodu ostatní přitahuje. Pomineme-li, že atraktivní tak může být nejen člověk, ale také např́iklad město, plat, nabídka, či pobyt u moře, tím nejsilnějším, co hodnotitele v tomto výzkumu na stárnoucích obličejích žen ,ppritahovalo“, byly pozitivní osobnostní rysy, které z nich na první pohled vycítili. Přestože se jednalo o první dojem a hodnotitelé obličeje na fotografiích předtím nikdy neviděli, jakoby si do nich promítali své představy o tom, jak má vypadat tvář stárnoucí ženy s přátelským a bezproblémovým charakterem.

Studium atraktivity lidského obličeje v kontextu stárnutí je v určitém slova smyslu novátorské, takže se neubrání jistým limitům. Již samotné oslovování případných aktérů k pořízení obličejových fotografií $\mathrm{v}$ př́śslušné věkové kategorii $\mathrm{s}$ tím, že jejich fotografie budou posuzovány $\mathrm{z}$ hlediska atraktivity, není snadné. Navíc současnou společností shodně vnímaná, vesměs negativní zkušenost $\mathrm{s}$ všudy prŕitomnými tazateli marketingových průzkumů či $\mathrm{s}$ vyplňováním různých dotazníků spokojenosti, se stala podvědomou překážkou v oslovování těchto aktérů př́mo na ulici. Pro zajištění větší důvěryhodnosti celého výzkumu se jako schůdnější nakonec ukázalo pořizovat fotografie během akcí pořádaných Západočeskou univerzitou v Plzni, jichž jsem, jako její zaměstnanec, pravidelnou součástí. Účast lidí příslušné věkové kategorie byla předpokládána na dvou akcích. Jednalo se o přednáškový cyklus Fakulty zdravotnických studií ZČU s názvem „Den zdravi“" pořádaný pro účastníky Univerzity třetího věku a dále o „Dny vědy a techniky“. Na krku s visačkou ZČU prozrazující vedle mého jména také titul (MUDr.) a fakt, že jsem zástupce vedoucího jisté katedry, se „nábor“ dobrovolníků k fotografování značně usnadnil. Zároveň jsem pro účastníky „Dne zdravi““ byla lektorkou, která jim přednášela o pitném režimu, inkontinenci a funkci lymfatického systému, čímž byla má důvěryhodnost coby výzkumníka zajištěna.

Z hlediska atraktivity bylo posuzováno jen deset fotografií, což ovšem mělo svůj důvod vzhledem k následnému využití programu Anthropac k párovému srovnávání, ve kterém je tento počet nejefektivnější. Aby byla zachována poměrná časová nenáročnost při administraci dotazníků $\mathrm{s}$ obličejovými páry $\mathrm{v}$ rámci následného výzkumu, kterého se mělo zúčastnit sto dvacet respondentů, bylo nutné původní počet třiceti fotografií zredukovat na pouhých deset. Pokud by 
bylo použito původních třicet fotografíí, objevilo by se v jednom dotazníku 460 různých kombinací párů, což z hlediska udržení pozornosti hodnotitele nebylo proveditelné. Jako únosný se zdál počet 45 párových kombinací na jednoho respondenta, čehož bylo dosaženo užitím jen deseti obličejových fotografií. Nejprve byl každý ze souborů zredukován na polovinu (15) vyřazením fotografií, které nebyly dostatečně kvalitní a těch, kde byly obličeje př́liš vrásčité. O eliminaci zbylých pěti fotografií rozhodlo následně deset dobrovolníků, kteří se dalšího výzkumu neúčastnili a jejichž úkolem bylo vybrat typově podobné obličeje a náhodným výběrem některé z nich vyloučit.

Výsledky této studie naznačují, že jde spíše o osobní komponentu atraktivity, která stárnoucí obličej ženy činí pro ostatní přitažlivý. Zároveň je z nich ale patrné, že jsou to právě ženy tohoto věku, které více podléhají všudy propagovanému mýtu krásy a osobní atraktivitu ocení až u té, která o sebe pečuje pravidelnými kosmetickými zásahy. Vzhledem k tomu, že starší respondentky tvořily jen $25 \%$ (30) z celkového počtu sto dvaceti respondentů, je do budoucna k ověření výše uvedených výsledků zapotřebí rozšiřit jejich počet a s použitím stejných fotografií ve výzkumu pokračovat.

\section{Závěr}

Zde prezentovaná studie neměla ambice provádět morfometrická měření ke zjištění symetrie či průměrných proporcí a stejně tak nebylo jejím záměrem zjišt'ovat konkrétní obličejové rysy, které jej eventuelně činí fyzicky atraktivním. V jejím pozadí se skrývá skromný dotaz o tom, zdali i stárnoucí ženský obličej může být vnímán jako atraktivní a pokud ano, o jakou komponentu (fyzickou či osobní) atraktivity se jedná.

Závěrem je možné konstatovat, že atraktivita se s věkem proměňuje v sympatie a „krásnou“ se tvář ženy stává především pro kladné pocity, které v ostatních dokáže vyvolat. Mladší muži v ní hledají „pečovatelku“, mladší ženy někoho, kdo s nimi nebojuje, ale i přes jejich mládí s nimi dokáže „vyjít“ a starší muži v ní hledají bezproblémového „prrítele“. S tím se ovšem starší ženy jakoby nechtěly smírit a teprve tu, která pečuje o svůj vzhled a dokáže se stárnutím bojovat, vnímají jako svůj vzor a jako někoho, kdo si „zaslouži“ být spokojený, optimistický, vyrovnaný, oblíbený a št'astný.

\section{Literatura}

Berman, P. W., O’Nan, B. A., \& Floyd, W. (1981). The double standard of aging and the social situation: judgments of attractiveness of the middle-aged woman. Sex Roles, 7, 87-96.

Deutsch, F. M., Zalenski, C. M., \& Clark, M. E. (1986). Is there a double standard of aging? Journal of Applied Social Psychology, 16, 771-785.

Enquist, M., Arak, A. (1994). Symmetry, beauty, and evolution. Nature, 169-172.

Ferjenčík, J., \& Nišponská, M. (1996). Vplyv výzoru tváre a sociálnej roly na vytváranie dojmu o osobe. Československá psychologie, 1, 39-45.

Grammer, K., \& Thornhill, R. (1994). Human (Homo sapiens) facial attractiveness and sexual selection: The role of symmetry and averageness. Journal of Comparative Psychology, 108, 233242.

Hume, D. K., \& Montgomerie, R. (2001). Facial attractiveness signals different aspects of „quality“ in women and men. Evolution and Behavior, 22, 93-112.

Johnston, R. A., \& Barry, C. (2001). Best face forward: similarity effects in repetition priming of face recognition. Quarterly Journal of Experimental Psychology A, 54, 383-396. 
Jones, B. C., Little, A. C., Penton-Voak, I. S., Tiddeman, B. P., Burt, D. M., \& Perrett, D. I. (2001). Facial symmetry and judgements of apparent health. Support for a ,good genes“ explanation of the attractiveness-symmetry relationship. Evolution and Human Behavior, 22, 417-429.

Kerlinger, F. N. (1972). Základy výzkumu chování. Pedagogický a psychologický výzkum. Praha: Academia.

Kowner, R. (1996). Facial asymmetry and attractiveness judgement in developmental perspective. Journal of Experimental Psychology, 22, 662-675.

Laurence, M. W. (1964). Sex differences in the perception of men and women at four different ages. Journal of Gerontology, 19, 343-348.

Malatesta, C. Z., Fiore, M. J. \& Messina, J.J. (1987). Affect, personality, and facial expressive characteristics of older people. Psychology and Aging, Vol 2(1), 64-69.

Marhánková Hasmanová, J. (2008). Genderové nerovnosti ve stáří: marginalizace a zvýhodnění žen ve stáŕí. Gender, rovné př́ležitosti, výzkum, 8 (2), 28-36.

Mealey, L., Bridgstock, R. \& Townsend, G. C. (1999). Symmetry and perceived attractiveness: A monozygotic co-twin comparison. Journal of Personality and Social Psychology, 76 (1), 151-158.

Mealey, L. (2000). Sex differences. Developmental and Evolutionary Strategies. Academic Press.

Monin, B. (2003). The warm glow heuristic: When liking leads to familiarity. Journal of Personality and Social Psychology, 85 (6) 1035-1048.

Nowak, C. A. (1977). Does youthfulness equal attractiveness? In Looking Ahead. Eds. Troll, L. E., Israel, J. \& Israel, K. Engelwood Cliffs, N. J.: Prentice-Hall, 59-64

Perrett, D. I., Burt, D. M., Penton-Voak, I. S., Lee, K. J., Rowland, D. A., \& Edwards, R. (1999). Symmetry and human facial attractiveness. Evolution and Human Behavior, 20, 295-307.

Rhodes, G., Proffitt, F., Grady, J. M., \& Sumich, A. (1998). Facial symmetry and perception of beauty. Psychonomic Bulletin \& Review, 5, 4, 659-669.

Rhodes, G., Zebrowitz, L. A., Clark, A., Kalick, S. M., Hightower, A., \& McKay, R. (2001). Do facial averageness and symmetry signal health? Evolution and Human Behavior, 22, 31-46.

Rubenstein, A. J., Langlois, J. H., \& Roggman, L. A. (2002). What Makes a Face Attractive and Why: The Role of Averageness in Defining Facial Beauty. In: Rhodes G, Zebrowitz LA. (2002). Facial attractiveness: Evolutionary, cognitive, and social perspectives. Ablex: Westport, CT.

Simmons, L. W., Rhodes, G., Peters, M., \& Koehler, N. (2004). Are human preferences for facial symmetry focused on signals of developmental instability? Behavioral Ecology, 15(5), 864-871.

Slaměník, I., \& Výrost, J. (2008). Sociálni psychologie 2. Přepracované a doplněné vydání. Praha: Grada Publishing.

Slaměník, I. (2011). Emoce a interpersonální vztahy. Vyd. 1. Praha: Grada Publishing.

Sontag, S. (1972). The double standard of aging. Saturday Review of Literature, 39, 29-38.

Thornhill, R., \& Gangestad, S. W. (1999). Facial attractiveness. Trends in Cognitive Sciences, 1364-6613, 452-460.

Ussher, J. M. (2006). Managing the monstrous feminine. Regulating the Reproductive Body.

London: Routledge. 


\section{O autorce}

MUDr. Lada Pavlíková působí jako odborný asistent na Katedře teoretických oborů Fakulty zdravotnických studií ZČU v Plzni a zároveň je doktorandkou na Katedře antropologie Filozofické fakulty ZČU v Plzni, kde se věnuje výzkumu percepce lidského obličeje s ohledem na atraktivitu a proces stárnutí. V minulých letech pưsobila jako odborná asistentka na Ústavu anatomie Lékařské Fakulty UK v Plzni a jako lektorka anatomie na University of Leeds, Faculty of Biological Sciences, Institute of Membrane and Systems Biology, United Kingdom.

\section{Kontaktní údaje}

Adresa: Katedra teoretických oborů, Fakulta zdravotnických studií ZČU, Tylova 57, 30614 Plzeň E-mail: lpavliko@ktb.zcu.cz

Pavlíková, L. (2014). Sympatie jako „ekvivalent” atraktivity obličeje stárnoucích žen. E-psychologie [online], 8, 3, 33-43 [cit. vložit datum citování]. Dostupný z WWW:

$<$ http://e-psycholog.eu/pdf/pavlikovalada.pdf>. ISSN 1802-8853. 